ISSN 1392-3196 / e-ISSN 2335-8947

Zemdirbyste-Agriculture, vol. 104, No. 3 (2017), p. 209-218

DOI 10.13080/z-a.2017.104.027

\title{
Influence of wild oat plant density on spring wheat yield
}

\author{
Jevgenija NECAJEVA, Zane ERDMANE, Anda ISODA-KRASOVSKA, \\ Jolanta CURISKE, Ieva DUDELE, Laura GAILE, Lelde STIRNA, \\ Kaspars RANCANS, Dainis POLIS, Liene SPURINA \\ Latvian Plant Protection Research Centre, Latvian University of Agriculture \\ Struktoru 14A, 1039 Riga, Latvia \\ E-mail: jevgenija.necajeva@laapc.lv
}

\begin{abstract}
Wild oat (Avena fatua L.) is the most serious weed infesting cereal fields in Latvia. To predict possible yield loss at different wild oat densities field trials were established in four consecutive years, each year in a different spring wheat field in the southern part of Latvia. Growth dynamics and biomass of both crop and wild oat and grain yield were measured. Yield loss model developed by Cousens (1985) and exponential decay model were fitted to the data from each year. Grain yield and biomass of both spring wheat and wild oat significantly differed between the years. The average grain yield of spring wheat in all treatments was $4443.38-7127.02 \mathrm{~kg} \mathrm{ha}^{-1}$. The targeted wild oat density was $0,1,2,4,8,16,32,100,200$ and 500 plants $\mathrm{m}^{-2}$. The achieved density in the field trial reached from 0 to 332-466 plants $\mathrm{m}^{-2}$. The emergence of wild oat seedlings lasted for 35 to 56 days after sowing, depending on the year. The initial hypothesis that low wild oat plant density may cause grain yield loss of spring wheat was supported by the results of the field trials. There was substantial variation in model parameters among the years of the trials, $5 \%$ yield loss was estimated to result from wild oat density ranging from 3 to 54 plants $\mathrm{m}^{-2}$ in different years. The variation of spring wheat yield loss and wild oat competitiveness might be explained by different meteorological conditions in the years 2013-2016 and different nutrient supply in the trial fields. Further research is necessary to find the most influential factors that determine yield loss caused by wild oat. The results are important to raise awareness of the harm caused by wild oat in cereals in the Baltic region.
\end{abstract}

Key words: Avena fatua, spring wheat, yield loss.

\section{Introduction}

The incidence of wild oat (Avena fatua L.) was recorded in the majority of municipal parish territories of Latvia, in $17 \%$ parish territories the incidence was high (several infested fields registered in the parish territory, where wild oat had taken over the entire field and was not controlled with herbicides, neighbouring fields were also infested), according to surveys conducted in 2013 and 2014 (Necajeva et al., 2015). Wild oat has been known as a weed in spring cereals in Latvia for several decades, but up to recent years there have been few studies dedicated to its effect on yield in local conditions. While zero-tolerance to wild oat is required from seed growers, many farms that grow cereals for food, fodder or other uses have fields with different degrees of infestation. Occasionally growers buy uncertified seed contaminated with wild oat that contributes to the spread of this weed. A similar problem is described in Estonia, where $76 \%$ of spring cereal fields were infested with wild oat in 1999 (Uusna, 2006).
Descriptive yield loss models have been used to simulate interaction of different crop and weed species and since being developed in the 1980-ies the equations in these models are adequate for prediction and visualization of yield loss caused by weeds. Recently yield loss-models have been developed, for example, for rice in competition with Echinochloa crus-galli and Eleocharis kuroguwai (Moon et al., 2010), sugar beet in competition with Polygonum convolvulus (Odero et al., 2010), soybean in competition with Conyza bonariensis (Trezzi et al., 2014) and maize in competition with volunteer soybean (Alms et al., 2016). While not explaining actual mechanisms of the interaction, descriptive models are sufficiently simple and can be useful for wider communication and dissemination of research results (Renton, Chauhan, 2016). This objective is particularly important in Latvia, because it is necessary to raise awareness of the potential harm caused by wild oat.

There are different reported estimates of wheat yield loss at certain wild oat densities. Spring wheat yield

Please use the following format when citing the article:

Necajeva J., Erdmane Z., Isoda-Krasovska A., Curiske J., Dudele I., Gaile L., Stirna L., Rancans K., Polis D., Spurina L. 2017. Influence of wild oat plant density on spring wheat yield. Zemdirbyste-Agriculture, 104 (3): 209-218 DOI 10.13080/z-a.2017.104.027 
reduction of $26.9 \%$ and $40.8 \%$, at unfertilized and fertilized plots, respectively, was reported at approximately 96 wild oat plants $\mathrm{m}^{-2}$ in the study in North Dacota, USA (Bell, Nalewaja, 1968). The effect of wild oat on yield loss in spring wheat was simulated depending on the density of wheat stand: reduction of yield loss by $20 \%$ was expected at 5.5 plants $\mathrm{m}^{-2}$ in a stand with low density $\left(100\right.$ plants $\left.\mathrm{m}^{-2}\right)$ or by 38 plants $\mathrm{m}^{-2}$ in a very dense stand (700 plants $\left.\mathrm{m}^{-2}\right)$ in a study conducted in California, USA (Carlson, Hill, 1985). Likewise, yield loss in spring barley at 95 wild oat plants $\mathrm{m}^{-2}$ was lower in denser crop stand, yield loss ranged from $11 \%$ to $36.4 \%$ depending on the density of the stand in a study in Idaho, USA (Evans et al., 1991). Martin et al. (1987) reported that wheat grain yield loss caused by 50 wild oat plants $\mathrm{m}^{-2}$ was $21 \%$ in a study conducted in Australia. At low wild oat density percentage of yield loss is related to weed density linearly. Wilson et al. (1990) in a study conducted in UK estimated that in spring barley and winter wheat yield loss could be approximately $1 \%$ for each wild oat plant. There are few recent studies on the yield loss caused by wild oat, but as agricultural methods and crop cultivars are constantly evolving, it is very important to make such estimates to be able to emphasize that timely control of wild oat is economically important.

Cousens (1985) proposed the use of rectangular hyperbolic function to describe the effect of added weed density on yield loss, as a simple model with biologically meaningful parameters. Parameters of this model depend on the crop species; weed species, meteorological conditions of the particular year and, potentially, other factors that influence crop yield and competitiveness of both crop and weeds. The parameters are the rate of yield decrease at low weed densities or the initial slope of the curve (I), the maximum \% of yield loss at infinite weed density (A) and yield in the absence of weeds $\left(\mathrm{Y}_{0}\right)$. The equation of the model is $\mathrm{y}=\mathrm{I} \times \mathrm{x} /(1+\mathrm{I} \times \mathrm{x} / \mathrm{A})$. The ratio between I and A characterizes competitiveness of the weed in particular conditions. The yield loss model that uses rectangular hyperbolic function has been incorporated into the $R$ package $d r c$ that can be used for crop-weed interaction analysis as well as dose-response curves, which is its main function (Ritz et al., 2015). Ma et al. (2016) used both the rectangular hyperbolic function and the two-parameter hyperbolic decay curve to relate weed density with cotton yield loss and yield, respectively. The hyperbolic decay curve was used to estimate the density of velvetleaf plants per square meter that would reduce cotton yield to $50 \%$ of weed-free control.

The aim of this study was to experimentally test the influence of wild oat competition on grain yield of spring wheat in Latvian conditions and use models relating weed density and crop yield to characterize this influence. The hypothesis was that grain yield of spring wheat is affected already by small density of wild oat. This knowledge is required for decision making in plant protection and assessing potential yield losses caused by the wild oat. Spring wheat was chosen because it is the second major cereal crop cultivated in Latvia.

\section{Materials and methods}

Location of the trials. A field trial was established each year during the period from 2013 to 2016 in the southern part of Latvia, each trial in a different field. Table 1 summarizes the soil properties in each of the fields, the soil type was Luvisol (LV).

Table 1. Soil properties and coordinates of the four fields where field trials were established in 2013-2016

\begin{tabular}{|c|c|c|c|c|c|c|c|c|}
\hline \multirow{2}{*}{ Year } & \multirow{2}{*}{$\begin{array}{c}\mathrm{P}_{2} \mathrm{O}_{5} \\
\mathrm{mg} \mathrm{kg}^{-1}\end{array}$} & \multirow{2}{*}{$\begin{array}{c}\mathrm{K}_{2} \mathrm{O} \\
\mathrm{mg} \mathrm{kg}^{-1}\end{array}$} & \multirow{2}{*}{$\mathrm{pH}_{\mathrm{KCl}}$} & \multirow{2}{*}{$\begin{array}{c}\text { Organic } \\
\text { matter \% }\end{array}$} & \multicolumn{3}{|c|}{ NPK fertilizer kg ha ${ }^{-1}$} & \multirow{2}{*}{ Field coordinates } \\
\hline & & & & & $\mathrm{N}$ & $\mathrm{P}$ & $\mathrm{K}$ & \\
\hline 2013 & 115 & 100 & 7.2 & 3.0 & 63 & 63 & 63 & $\begin{array}{l}56^{\circ} 23^{\prime} 31.0^{\prime \prime} \mathrm{N} \\
23^{\circ} 47^{\prime} 39.8^{\prime \prime} \mathrm{E}\end{array}$ \\
\hline 2014 & 335 & 165 & 6.9 & 1.7 & 40 & 40 & 40 & $\begin{array}{l}56^{\circ} 27^{\prime} 02.6^{\prime \prime} \mathrm{N} \\
23^{\circ} 44^{\prime} 42.4^{\prime \prime} \mathrm{E}\end{array}$ \\
\hline 2015 & 194 & 78 & 7.0 & 2.8 & 38 & 38 & 38 & $\begin{array}{l}56^{\circ} 23^{\prime} 51.3^{\prime \prime} \mathrm{N} \\
23^{\circ} 44^{\prime} 43.0^{\prime \prime} \mathrm{E}\end{array}$ \\
\hline 2016 & 94 & 100 & 7.4 & 2.5 & 25 & 103 & 123 & $\begin{array}{l}56^{\circ} 24^{\prime} 09.4^{\prime \prime} \mathrm{N} \\
23^{\circ} 44^{\prime} 28.8^{\prime \prime} \mathrm{E}\end{array}$ \\
\hline
\end{tabular}

Note. Fields were located in Sesava parish, Jelgava Municipality, Latvia.

Design and establishment of the trials. The trials were arranged in a randomized complete block design with nine wild oat (Avena fatua L.) densities and control with no wild oat plants, with three replications in each trial. The nine targeted densities of wild oat were 1, 2, 4, $8,16,32,64,100,200$ and 500 plants $\mathrm{m}^{-2}$. Each treatment block consisted of ten $1 \times 3 \mathrm{~m}$ plots divided into three $1 \mathrm{~m}^{2}$ squares. The spring wheat sowing dates were 07052013 , 2404 2014, 21042015 and 0205 2016. Trial plots were established and wild oat seeds sown on the same day as spring wheat. The preceding crops were: potatoes (2013), winter oilseed rape that did not overwinter (2014), spring barley (2015) and winter barley (2016). The soil was cultivated and rolled in spring 2013; in 2013 and in 2015 ploughed in the previous autumn; in years 2014-2016 the soil was compacted before sowing; in 2014 the soil was also harrowed in spring.

Spring wheat sowing rate was $250 \mathrm{~kg} \mathrm{ha}^{-1}$ in 2013, $280 \mathrm{~kg} \mathrm{ha}^{-1}$ in 2014, and $300 \mathrm{~kg} \mathrm{ha}^{-1}$ in 2015 and 2016. In 2013 and 2014 spring wheat cultivar 'Zebra', in 2015 and 2016 spring wheat cultivar 'Mooni' was used. NPK fertilizer was applied at sowing date or within two weeks after sowing. Ammonia nitrate was applied at the rate of $200 \mathrm{~kg} \mathrm{ha}^{-1}$ at the tillering stage (BBCH 13-22) 
of spring wheat. Dicotyledonous weeds were controlled with MCPA 750 (2013, 2014 and 2015) or Starane XL (2016) at a rate of $1.0 \mathrm{~L} \mathrm{ha}^{-1}$. Insecticides, fungicides and growth regulators were used as necessary.

Wild oat seeds were collected in 2009 and stored at room temperature. Each year before establishing the trial, germination was tested and weight of 100 geminating seeds was calculated. Wild oat seeds that were planted in the plots with low targeted density were counted, but starting at 32 plants $\mathrm{m}^{-2}$ the necessary amount of seeds was weighed. Wild oat seeds were planted at 3-5 cm depth (except in 2013 when seeds were sown at the surface) and rolled over with grass roller. To protect the seeds against birds, small rodents and mechanical damage all plots were covered with white frost-protection cloth that was removed as soon as spring wheat started to germinate. If the number of wild oat plants exceeded the target density, plants were manually removed.

Data collection and statistical analysis. Wild oat emergence was monitored weekly; emerged seedlings were recorded in the entire plot. Shoot biomass of both wild oat and spring wheat was measured twice. First, at flag leaf development stage (BBCH 39) of wheat and then at harvest. Each time above-ground parts of the plants were collected from $1 \mathrm{~m}^{2}$ in each treatment. The actual number of plants $\mathrm{m}^{-2}$ was counted at the same time when biomass was determined. Fresh weight was determined by weighing the plants immediately after collection; dry weight was determined by weighing the plants after one month of drying at room temperature. All wheat ears from $1 \mathrm{~m}^{2}$ were thrashed and grain was cleaned and weighed to determine grain yield (recalculated as $\mathrm{kg} \mathrm{ha}^{-1}$ ). Height and development stage of wheat and wild oat was recorded for 10 individual plants marked in each plot. Soil samples were taken at each field before sowing and were analysed at the Agrochemical Laboratory, Agrochemical Department, State Plant Protection Service, Latvia. Soil $\mathrm{pH}, \%$ of organic matter, potassium and phosphorus concentrations were determined.

Analysis of variance was performed to test the difference in spring wheat grain yield and spring wheat biomass and wild oat biomass at flag leaf stage of the spring wheat. Year and block were included as factors, then a model without block was compared to the initial model using Chi square test. If no significant difference was found between the models, model without block factor was chosen. After analysis, diagnostic plots were examined to ensure that assumptions of the analysis are met. All analysis was performed in package $R$, version 3.2.4 (R Core Team, 2016) using package R-studio, version 0.99.903 (R Studio Team, 2015).

Dunnett's test for multiple comparisons with Bonferroni adjustment was performed using mulcomp package in $R$ (Hothorn et al., 2008). The relationship between spring wheat grain yield loss and wild oat density was simulated using rectangular hyperbolic function described by Cousens (1985) and Ritz et al. (2012). To fit the rectangular hyperbolic curve $\mathrm{drm}$ function from the package $d r c$ was used, specifying the two-parameter Michaelis-Menten as the model, then function yieldLoss was used to estimate the parameters I and A. Yield loss was calculated as \% of yield at each plot with wild oat related to wild oat free plot in the same block. Yield in the wild oat free plots was not included in the dataset. The equation of the yield loss model curves was $\mathrm{y}=\mathrm{d} /(1+$ $(\mathrm{e} / \mathrm{x}))$, where $\mathrm{y}$ is yield loss ( $\%$ of wild oat free control) and $\mathrm{x}$ is density of wild oat (plants $\mathrm{m}^{-2}$ ). Parameter " $\mathrm{d}$ " corresponds to the maximum estimated yield loss (\%) and parameter " $\mathrm{e}$ " corresponds to $\mathrm{x}$ value at which yield loss is halfway between 0 and $\mathrm{d}$.

The relationship between spring wheat grain yield and wild oat density was simulated using exponential decay curve model with three parameters. Data was fitted using $d r m$ function. Curves were fitted to the entire dataset, including wild oat free (control) plots.

The equation used to fit the curves was $y=c+(d$ $-\mathrm{c}) \times \exp ^{(-(\mathrm{x} / \mathrm{e}))}$, where $\mathrm{y}$ is yield $\left(\mathrm{kg} \mathrm{ha}^{-1}\right)$ and $\mathrm{x}$ is density of wild oat (plants $\mathrm{m}^{-2}$ ). Parameter "c" corresponds to the minimum and parameter " $\mathrm{d}$ " to the maximum estimated yield, parameter " $e$ " determines steepness of the decay. Function ED was used to estimate wild oat densities at which 5, 10, 20 and 50\% yield loss would be reached.

\section{Results}

Spring wheat grain yield varied among the years (Fig. 1), with the highest yields recorded in 2014 and 2015. Similarly, total biomass or wild oat collected at the time when spring wheat reached flag leaf stage (BBCH 39) was highest in 2014. In 2015 and 2016, a different spring wheat cultivar was used, which can explain generally lower spring wheat biomass in these years, while wheat biomass was highest in 2013 due to small density of wild oat.

In 2016, dry weather in spring, especially in the last ten-day period of April and the first ten-day period of May, impaired germination that resulted in lower wild oat density (Tables 2-3).

In 2013, wild oat seeds were sown on soil surface, which explains poor emergence and low densities in that year. In all years, targeted wild oat density was reached in the treatments where it was small, up to 16 plants $\mathrm{m}^{-2}$ (Table 3 ). Spring wheat reached flag leaf development stage (BBCH 39) in five (2013), seven (2014), eight (2015) and six (2016) weeks after sowing. Average plant height of spring wheat at this stage was $59.3 \mathrm{~cm}$ (standard deviation (SD) 2.0) in $2013,51.1 \mathrm{~cm}$ (SD 1.4) in 2014, $46.0 \mathrm{~cm}$ (SD 1.7) in 2015 and 33.7 (SD 1.7) in 2016 (average height in all plots). When the crop development stage was $\mathrm{BBCH} 39$, wild oat reached $\mathrm{BBCH}$ stage 35 to 37 (2014 and 2015), ranging from 31 to 49 , depending on the year. Average height of wild oat at the same time was $55.0 \mathrm{~cm}$ (SD 5.6) in 2013, $64.4 \mathrm{~cm}$ (SD 5.3) in 2014, $49.5 \mathrm{~cm}$ (SD 3.3) in 2015 and $22.3 \mathrm{~cm}$ (SD 4.5) in 2016. The height of wild oat plants exceeded the height of wheat plants when wild oat panicles began to develop.

Time of emergence of wild oat and spring wheat seedlings is summarized in Table 4. Large standard deviations are explained by differences between treatments with low wild oat densities where emergence 


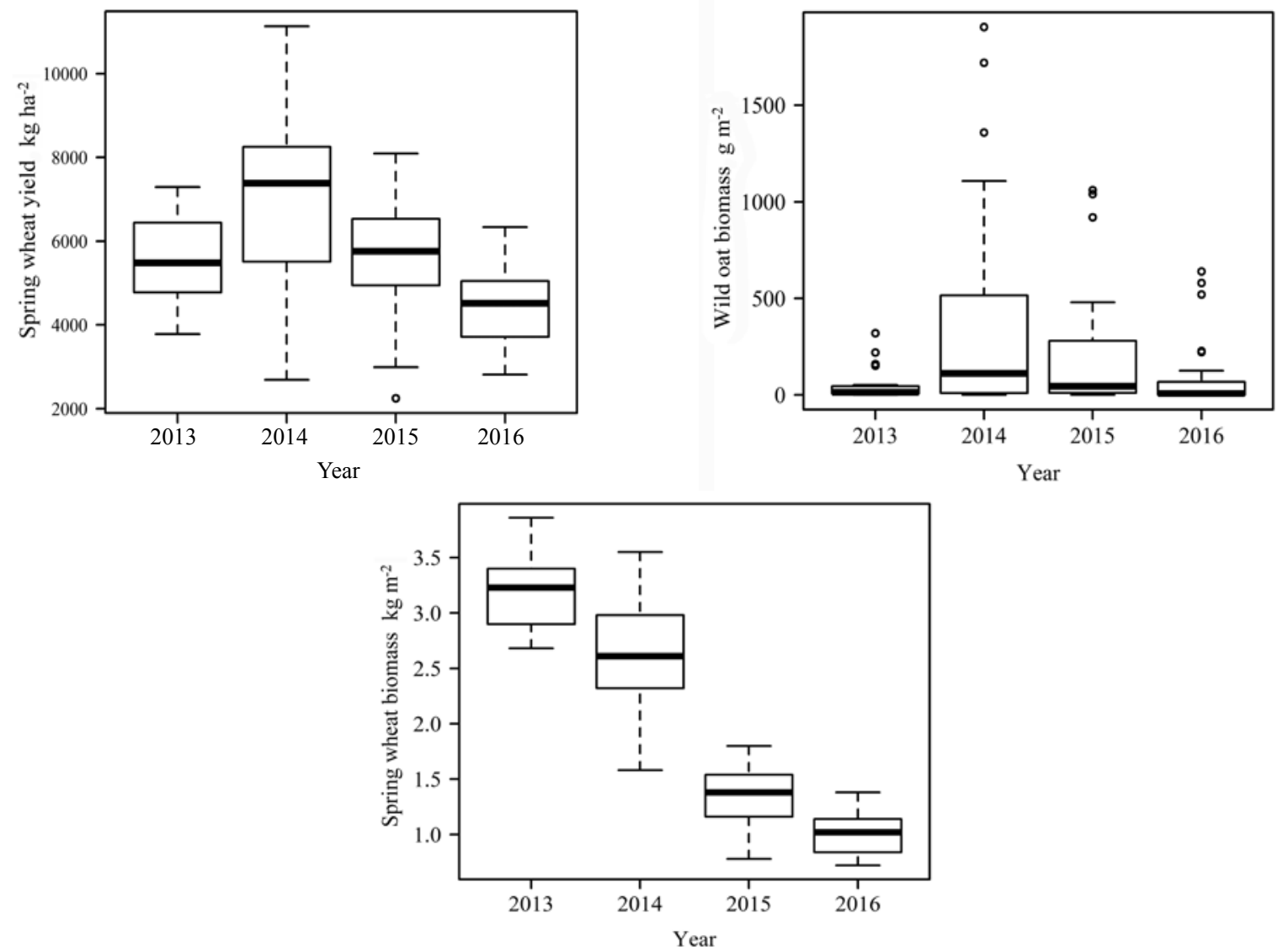

Note. Analysis of variance and multiple comparisons were performed using Dunnett's test with Bonferroni adjustment, values significantly different from the reference group (year 2013) are marked with an asterisk.

Figure 1. Grain yield of spring wheat, biomass of spring wheat and wild oat at wheat flag leaf stage in 2013-2016

Table 2. Meteorological conditions in each of the trial years: monthly precipitation and mean daily temperature in each year and the long-term average (30-year period)

\begin{tabular}{|c|c|c|c|c|c|c|c|c|c|c|c|}
\hline \multirow{2}{*}{ Year } & \multicolumn{5}{|c|}{ Temperature ${ }^{\circ} \mathrm{C}$} & \multirow{2}{*}{ Year } & \multicolumn{5}{|c|}{ Precipitation $\mathrm{mm}$} \\
\hline & April & May & June & July & August & & April & May & June & July & August \\
\hline 2013 & 4.2 & 15.0 & 17.7 & 17.7 & 16.8 & 2013 & 32.2 & 58.7 & 49.0 & 89.5 & 61.9 \\
\hline 2014 & 7.7 & 12.0 & 14.0 & 19.5 & 17.2 & 2014 & 48.8 & 86.5 & 111.7 & 83.6 & 75.6 \\
\hline 2015 & 6.5 & 10.6 & 14.4 & 16.4 & 17.8 & 2015 & 57.1 & 54.5 & 15.7 & 74.0 & 5.7 \\
\hline 2016 & 6.5 & 14.1 & 16.5 & 17.9 & 16.3 & 2016 & 53.6 & 24.6 & 60.0 & 95.0 & 85.8 \\
\hline $\begin{array}{l}\text { Long term } \\
\text { average }\end{array}$ & 5.3 & 11.7 & 15.4 & 16.6 & 15.9 & $\begin{array}{l}\text { Long term } \\
\text { average }\end{array}$ & 41.6 & 48.1 & 54.5 & 83.6 & 75.6 \\
\hline
\end{tabular}

Note. Temperature data were acquired from the Weather Station in Jelgava (28 km from the sites); precipitation data were acquired from the Weather Station at Poki (12 km from the sites), Latvia.

Table 3. Targeted wild oat density and achieved wild oat density (plants $\mathrm{m}^{-2}$ ) in different treatments in years 2013-2016

\begin{tabular}{ccccc}
\hline $\begin{array}{c}\text { Targeted } \\
\text { density }\end{array}$ & 2013 & 2014 & 2015 & 2016 \\
\hline 1 & 1 & 1 & 1 & 1 \\
2 & 2 & 2 & 2 & 1 \\
4 & 4 & 4 & 4 & 4 \\
8 & 8 & 8 & 8 & 6 \\
16 & 5 & 15 & 16 & 11 \\
32 & 2 & 24 & 32 & 22 \\
100 & 8 & 92 & 81 & 62 \\
200 & 31 & 155 & 138 & 126 \\
500 & 49 & 372 & 464 & 332 \\
\hline
\end{tabular}

was more uniform and treatments with high wild oat densities where emergence time was more uneven.

Values of parameters "d" and "e" in the yield loss model were 54.4 (standard error (SE) 7.53) and 22.4 (SE 11.9) in 2014, and 101.1 (SE 19.12) and 119.3 (SE 54.9 ) in 2015. Resulting curves are shown in Figure 2, the estimated parameters A and I and predictions of 5, 20 and $50 \%$ yield loss are summarized in Table 5 . The estimated coefficients for 2016 data model were not significant $(p>0.1)$, because data did not fit the hyperbolic curve. No adequate estimates were made for the 2013 data model. In the model for 2014 data the $p$ value for the estimate of the parameter "e" was 0.07 , but this model was accepted. Data for 2016 showed a linear, rather than 
Table 4. Emergence dynamics of wild oat seedlings and time of spring wheat emergence in years 2013-2016

\begin{tabular}{|c|c|c|c|c|c|c|c|c|}
\hline \multirow{3}{*}{$\begin{array}{l}\text { Days after } \\
\text { sowing } \\
\text { (DAS) }\end{array}$} & \multicolumn{8}{|c|}{ Emergence } \\
\hline & \multicolumn{2}{|c|}{2013} & \multicolumn{2}{|c|}{2014} & \multicolumn{2}{|c|}{2015} & \multicolumn{2}{|c|}{2016} \\
\hline & mean $\%$ & $\mathrm{SD}$ & mean $\%$ & SD & mean $\%$ & SD & mean $\%$ & SD \\
\hline 10 & 0.0 & 0.0 & 0.0 & 0.0 & 0.0 & 0.0 & 44.3 & 18.9 \\
\hline 14 & 63.4 & 21.5 & 45.1 & 45.3 & 52.7 & 13.5 & 54.2 & 18.8 \\
\hline 21 & 84.4 & 14.2 & 53.5 & 46.4 & 74.4 & 18.0 & 75.8 & 12.9 \\
\hline 28 & 96.3 & 4.0 & 92.8 & 7.7 & 85.8 & 8.1 & 73.4 & 16.2 \\
\hline 35 & 100.0 & 0.0 & 95.5 & 5.7 & 91.0 & 6.5 & 77.5 & 16.1 \\
\hline 42 & & & 95.5 & 5.7 & 98.1 & 1.7 & 100.0 & 0.0 \\
\hline 49 & & & 100.0 & 0.0 & 97.7 & 2.1 & & \\
\hline 56 & & & & & 100.0 & 0.0 & & \\
\hline $\begin{array}{c}\text { Wheat } \\
\text { emergence }\end{array}$ & $6 \mathrm{DAS}$ & & 14 DAS & & 10 DAS & & 9 DAS & \\
\hline
\end{tabular}

Note. SD - standard deviation; number of emerged seedlings was counted in each treatment and expressed as percentage of maximum emergence in the same treatment.


Notes. Results from three blocks at the same location each year are shown; data from different blocks are denoted with different characters.

Figure 2. Rectangular hyperbolic curves fitted to spring wheat yield loss at different wild oat densities (data from years 2014 and 2015)

Table 5. Parameters of the yield loss model derived from the rectangular hyperbolic curves fitted to spring wheat yield loss data at different wild oat densities in years 2014 and 2015

\begin{tabular}{cccccccccc}
\hline & 2014 & SE* & $\begin{array}{c}\text { Lower } \\
\text { CI** }\end{array}$ & $\begin{array}{c}\text { Upper } \\
\text { CI** }\end{array}$ & & 2015 & SE & \multicolumn{2}{c}{ Lower } \\
CI & Upper \\
CI
\end{tabular}

Notes. ${ }^{*}$ - standard error of the estimates; ** - upper and lower confidence intervals (95\%), estimated yield loss of 5, 20 and $50 \%$ was calculated using function ED in package $d r c$. Parameter A is estimated yield loss (\%) at infinite wild oat density, parameter I is the initial slope of the curve or rate of increase of yield loss at low wild oat density.

hyperbolic relationship between yield loss and wild oat density, and a much lower slope than in 2014 and 2015.

Exponential decay curves with three parameters could be fitted for data from all years, curves for 2014 and 2015 were similar in shape, although 2014 had higher intercept and slope was comparatively steeper (Fig. 3). Model parameters for data for 2013 and 2016 were not significant and the relationship appeared to be linear, so linear models were fitted to these data. Slope in the linear model fitted to 2013 data was not significant, but in the model fitted to 2016 data slope was -4.266 (SE 1.552, $p=0.0103$ ).

Values for wild oat density that would cause 5, 20 and $50 \%$ yield loss derived from the exponential decay models were lowest in 2014, followed by 2015 , values estimated for 2016 were approximately twice higher, but estimates for 2016 data had extremely large standard errors and confidence intervals (Table 6) and should be 

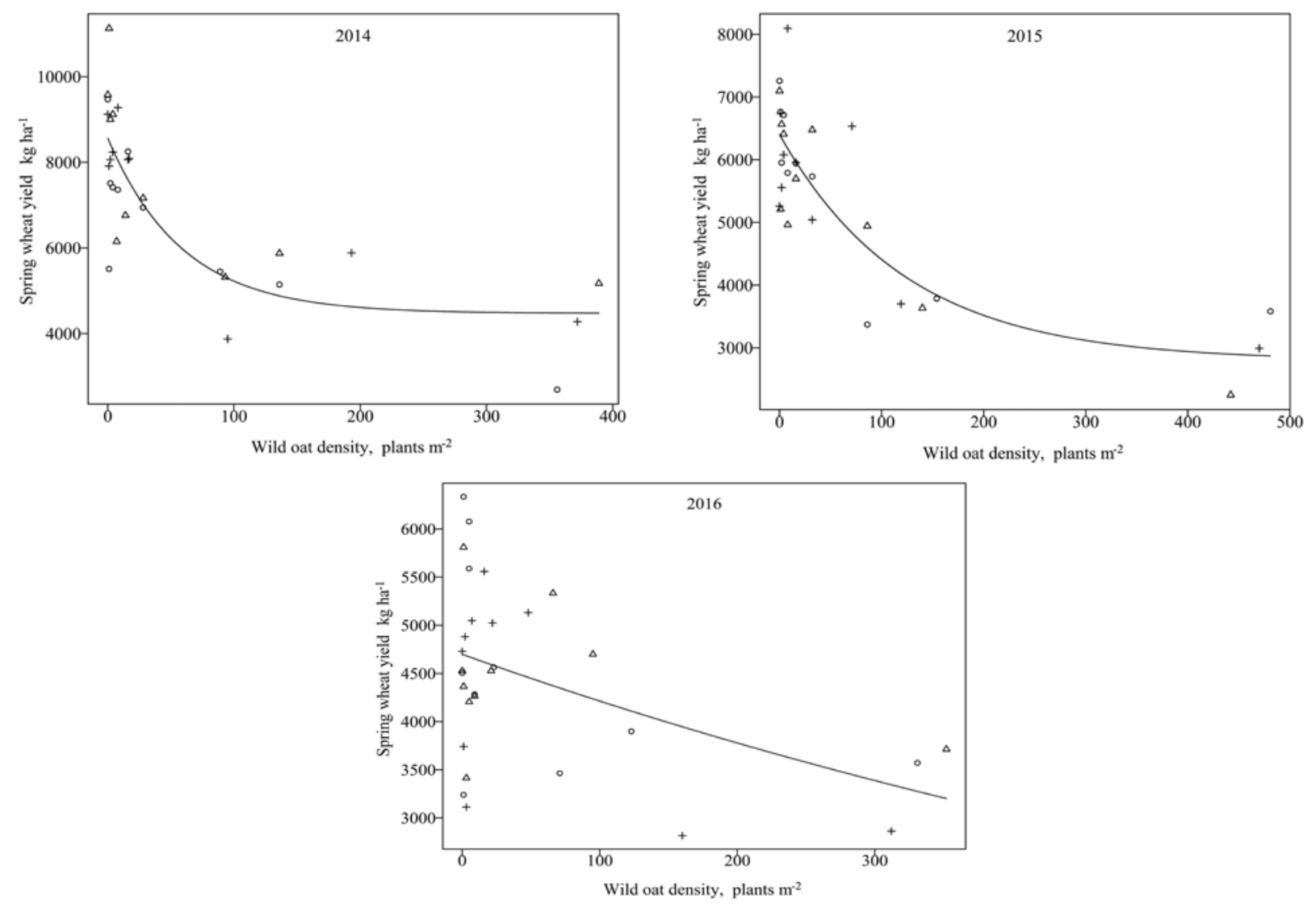

Note. Results from three blocks at the same location each year are shown; data from different blocks are denoted with different characters.

Figure 3. Exponential decay curves with three parameters fitted to spring wheat yield loss at different wild oat densities (data from years 2014-2016)

Table 6. Parameters of the yield decrease model derived from the exponential decay curves fitted to spring wheat yield data at different wild oat densities in years 2014 and 2015, including wild oat free plots

\begin{tabular}{|c|c|c|c|c|c|}
\hline & 2014 & SE* & Lower CI** & Upper CI** & $p$ \\
\hline $\mathrm{c}$ & 4472.37 & 656.78 & & & $<0.001$ \\
\hline d & 8562.73 & 353.04 & & & $<0.001$ \\
\hline e & 59.06 & 35.68 & & & 0.109 \\
\hline$-5 \%$ & 3.03 & 1.83 & -0.73 & 6.78 & \\
\hline$-20 \%$ & 13.18 & 7.96 & -3.15 & 29.51 & \\
\hline \multirow[t]{2}{*}{$-50 \%$} & 40.94 & 24.73 & -9.80 & 91.68 & \\
\hline & 2015 & SE & Lower CI & Upper CI & $p$ \\
\hline $\mathrm{c}$ & 2796.32 & 536.68 & & & $<0.001$ \\
\hline $\mathrm{d}$ & 6402.16 & 205.56 & & & $<0.001$ \\
\hline $\mathrm{e}$ & 124.31 & 45.43 & & & 0.011 \\
\hline$-5 \%$ & 6.38 & 2.33 & 1.60 & 11.16 & \\
\hline$-20 \%$ & 27.74 & 4.79 & 3.28 & 22.92 & \\
\hline \multirow[t]{2}{*}{$-50 \%$} & 86.17 & 31.49 & 21.56 & 150.77 & \\
\hline & 2016 & SE & Lower CI & Upper CI & $p$ \\
\hline $\mathrm{c}$ & 2503.02 & 3288.92 & & & 0.453 \\
\hline d & 4719.12 & 199.86 & & & $<0.001$ \\
\hline $\mathrm{e}$ & 322.88 & 766.33 & & & 0.668 \\
\hline$-5 \%$ & 17.07 & 39.31 & -63.58 & 97.73 & \\
\hline$-20 \%$ & 74.28 & 171.0 & -176.59 & 425.15 & \\
\hline$-50 \%$ & 230.73 & 531.18 & -859.16 & 1320.62 & \\
\hline
\end{tabular}

Notes. * - standard error of the estimates; ** - upper and lower confidence intervals (95\%), estimated yield loss of 5, 20 and $50 \%$ was calculated using function ED in package $d r c$. Parameter "c" corresponds to the minimum and parameter "d" to the maximum estimated yield, parameter "e" determines steepness of the decay. 
discarded. The linear model developed for 2016 data predicted yield loss of 5, 20 and $50 \%$ predicted at wild oat densities 54, 214 and 543 plants $\mathrm{m}^{-2}$, respectively.

Comparing the yield loss values predicted by the yield loss model (Table 5) with those predicted by the exponential decay model (Table 6), the values for 2015 are similar. In contrast for 2014 data the wild oat density that would cause 5,20 or $50 \%$ yield loss predicted by yield loss model is much lower than predicted by the exponential decay model, but standard errors are high in both models for 2014. Thousand grain weight (TGW) was negatively influenced by wild oat density but this influence was different in experimental years, and TGW did not correlate with the total grain yield (results not shown).

\section{Discussion}

Predictions of the models fitted to data acquired in this study are generally in agreement with the values reported in the literature, but large differences in yield and yield loss among the years must be explained.

Weed competitiveness relative to the crop is dependent on a large number of environmental and biological factors. Among the factors that influence wheat competition with wild oat are nitrogen fertilization and its application timing and method, crop stand density, crop cultivar and its growth parameters, such as height. Growth conditions in a particular year can potentially alter competitiveness as well.

Emergence of wild oat in the field is uneven, it can continue for several weeks and relative time of emergence can alter competitive ability of the weed. Moreover, uneven germination makes control of wild oat difficult, because new plants are likely to emerge after control measures were applied. Willenborg et al. (2005) in a study of the influence of time of emergence of wild oat on yield of common oat showed that early emerging wild oat causes more yield loss than late-emerging. Predicted yield losses caused by 100 wild oat plants $\mathrm{m}^{-2}$ in one of the experimental sites were $45 \%$ and $20 \%$, depending on the relative time of emergence of the wild oat, but the estimated slope parameter (I) was 0.4 , which is much lower than in the models in this study (Table 5), indicating lower competitive ability of oat comparing to spring wheat. The early emerging weeds have advantage in competition for light. In our experiments, spring wheat always emerged before or at the same time as wild oat (Table 4), thus potentially lowering competitive ability of the wild oat. In 2013 and 2016, when emergence of wild oat was delayed due to unfavourable conditions, its competition with spring wheat could have been weakened even more. In 2014, relatively late germination of spring wheat may have increased weed competition that corresponds to lower wild oat density causing 5, 20 and $50 \%$ yield loss (Table 6). The initial hypothesis was confirmed by the results of the study, because models predicted 5\% yield loss at 3-54 wild oat plants per square meter, depending on growth conditions.
One of the important factors that can affect spring wheat competition with wild oat is its ability to use resources. Many studies report that competition between wild oat and cereals changes at different rates of nitrogen fertilizer. In a study on the effect of nitrogen fertilizer application on yield loss in winter wheat caused by wild oat, the estimated slope parameter (I) ranged from 0.82 to 1.27 depending on the dose of nitrogen fertilizer and yield loss caused by 100 wild oat plants $\mathrm{m}^{-2}$ ranged from $31 \%$ to $45 \%$ (Pourreza et al., 2010). In the study by Carlsson and Hill (1986) spring wheat yield losses at 16 and 32 wild oat plants $\mathrm{m}^{-2}$ were smaller when no fertilizer was applied (17.5\% and $21.5 \%$, respectively) than when 67 $\mathrm{kg} \mathrm{ha}^{-1}$ nitrogen fertilizer was applied (34.1\% and 48.1\%, respectively) at crop stand density 350 plants $\mathrm{m}^{-2}$. This means that wild oat, as well as the crop, benefited from the fertilizer. Similar results were reported by Blackshaw et al. (2004) for spring wheat, where yield decrease in the presence of wild oat also depended on fertilization timing and method, because wild oat benefited from fertilizer that was surface broadcast and available to the weeds. However, Bradshaw and Brandt (2008) reported that in a replacement study with spring wheat competitive ability of wild oat did not increase at higher nitrogen fertilization rate. An earlier study on the effect of nitrogen and phosphorus fertilizers on wheat competition with wild oat showed that nitrogen, rather than phosphorus, increased wild oat competition (Sexsmith, Russell, 1962). On the other hand, additional phosphorus stimulated wild oat growth at high light intensity (Sharma et al., 1977). In contrast to wheat, phosphorus was shown to increase competitiveness of barley (Sharma, Vanden Born, 1977). Barley is more competitive than wheat and is capable of using resources more effectively and yield loss depends on growth conditions in particular year (Bell, Nalewaja, 1968). In this study, nitrogen fertilizer dose was the same each year, but phosphorus concentrations in the soil were highest in the years when both highest wheat yield and wild oat biomass were recorded (Table 1, Fig. 1). The different factors, such as crop species and stand density, nitrogen and phosphorus concentration in the soil and meteorological conditions can interact in a complicated way to result in decreased or increased competitiveness of both crop and weed, so further research is required.

Lutman et al. (1994) studied oat competition with different crops and concluded that high rainfall was increasing oat competition. High moisture is also favourable for development of wild oat and increases its competitiveness as a weed (Sharma et al., 1977; Sharma, Vanden Born, 1977). In the four years when this study was conducted, the highest rainfall was recorded in 2014 (Table 2). In a study conducted in Pakistan, in a dry and hot area, $72 \%$ grain yield loss of wheat was caused by 80-90 wild oat plants $\mathrm{m}^{-2}$ (Rahman et al., 2015). In this study in dry conditions observed in 2015 , competition of wild oat was smaller comparing to 2014 and $50 \%$ of grain yield loss estimated at 86 plants $\mathrm{m}^{-2}$ (Table 6).

The highest competitiveness of wild oat was estimated in the same years when both total wheat yield 
and wild oat biomass were highest, especially in 2014 (Fig. 1). It is therefore feasible to conclude that in the years when conditions were favourable for spring wheat and yields were higher, competitive ability of the wild oat was higher as well. Conversely, when conditions were unfavourable, yield could depend mostly on growth factors unrelated to wild oat density, as in 2013 and 2016. These factors can be meteorological conditions, plant nutrition and competition with dicotyledonous weeds. Accordingly, proportional yield loss was higher when total grain yield was higher, but when conditions were unfavourable or management poor, similar infestation level would result in smaller proportional yield loss. This conclusion must be treated with caution and further confirmed by field studies, because in the earlier research Bell and Nalewaja (1968) reported that percent of yield loss was higher in the site with dryer soil and lower nutrient concentration, i.e. less favourable for cereals and wild oat growth.

Lindquist et al. (1999) have simulated yield loss of maize at various giant foxtail densities in different years and different experimental sites. They concluded that the coefficients of the yield loss model that characterize competitiveness of giant foxtail were variable among the sites but not among the years. In this research, there have been considerable differences among the years in terms of actual spring wheat yield and both predicted maximum yield loss (parameter A) and weed competitiveness (parameter I). Variation of model parameters makes it difficult to make precise predictions of grain yield loss or economic losses (Lindquist et al., 1999). However, results obtained in different years and different sites show the range of potential yield loss caused by certain densities of wild oat in spring wheat crop in local climatic conditions. It is necessary to acquire more field data to be able to improve model accuracy and give predictions for yield loss at a range of possible environmental conditions in Latvia. Effect of fertilization, sowing date and crop stand density on wheat-wild oat competition must be studied in field trials to develop recommendations for integrated management of wild oat.

When further disseminating results of this research, it is important to stress that even when factors other than wild oat density may have greater influence on yield than the presence of wild oat, wild oat plants still produce seeds that can either contaminate the grain or, most probably, stay in the soil seed bank. Thus, the degree of infestation of the particular field will increase and potentially become a major problem.

\section{Conclusions}

1. The effect of wild oat (Avena fatua L.) on grain yield of spring wheat in Latvia can vary markedly among years.

2. Slow and uneven germination of wild oat poses difficulty for weed control and can influence weed competitive ability.

3. Models that describe relationship between yield or yield loss and wild oat density predict that loss of $5 \%$ of the yield can occur at wild oat densities from as low as 3 to 6 plants $\mathrm{m}^{-2}$ to as high as 54 plants $\mathrm{m}^{-2}$, depending on growth conditions in a particular site and year.

4. High moisture and moderate temperature are favourable for wild oat development and in absence of weed control can cause high grain yield loss of spring wheat.

5. Grain yield loss is higher when growth conditions are favourable for both spring wheat and wild oat development. When spring wheat grain yield is affected by unfavourable growth conditions, the effect of even high density of wild oat can be overlooked and infestation of the field would increase further due to the lack of adequate weed control.

\section{Acknowledgements}

The research was carried out as a part of the project "Integrated pest management for weed control in arable crops for sustainable use of the environment and resources" supported by European Agricultural Fund for Rural Development (EAFRD) and the project "Recommendations for effective control of wild oat and other widespread weed species in Latvia" supported by Latvian Ministry of Agriculture. We thank the leader of the project "Integrated pest management for weed control in arable crops for sustainable use of the environment and resources" Dr. Ineta Vanaga and the owner of the farm where the experimental plots were located.

We also thank the anonymous reviewers for the comments that helped to improve the quality of the manuscript.

Received 05122016 Accepted 25052017

\section{References}

1. Alms J., Clay S. A., Vos D., Moechnig M. 2016. Corn yield loss due to volunteer soybean. Weed Science, 64: 495-500. https://doi.org/10.1614/WS-D-16-00004.1

2. Bell A. R., Nalewaja J. D. 1968. Competition of wild oat in wheat and barley. Weed Science, 16: 505-508.

3. Blackshaw R. E., Molnar L. J., Janzen H. H. 2004. Nitrogen fertilizer timing and application method affect weed growth and competition with spring wheat. Weed Science, 52: 614-622.

https://doi.org/10.1614/WS-03-104R

4. Bradshaw R. E., Brandt R. N. 2008. Nitrogen fertilizer rate effects on weed competitiveness is species dependent. Weed Science, 59: 743-747.

5. Carlsson H. L., Hill J. E. 1985. Wild oat (Avena fatua) competition with spring wheat: plant density effects. Weed Science, 33: 176-181.

6. Carlsson H. L., Hill J. E. 1986. Wild oat (Avena fatua) competition with spring wheat: effects of nitrogen fertilization. Weed Science, 34: 29-33.

7. Cousens R. 1985. A simple model relating yield loss to weed density. Annals of Applied Biology, 107: 239-252. https://doi.org/10.1111/j.1744-7348.1985.tb01567.x 
8. Evans R. M., Thill D. C., Tapia L., Safii B., Lish J. M. 1991. Wild oat (Avena fatua) and spring barley (Hordeum vulgare) density affect spring barley grain yield. Weed Technology, 5: 33-39.

9. Hothorn T., Bretz F., Westfall P. 2008. Simultaneous inference in general parametric models. Biometrical Journal, 503: 346-363.

https://doi.org/10.1002/bimj.200810425

10. Lindquist J. L., Mortensen D. A., Westra P., Lambert W. J., Bauman T. T., Fausey J. C., Kells J. J., Langton S. J., Harvey R. G., Bussler B. H., Banken K., Clay S., Forcella F. 1999. Stability of corn (Zea mays)-foxtail (Setaria spp.) interference relationship. Weed Science, 47: 195-200.

11. Lutman P. J. W., Dixon F. L., Risiott R. 1994. The response of four spring-sown combinable crops to weed competition. Weed Research, 34: 137-146. https://doi.org/10.1111/j.1365-3180.1994.tb01981.x

12. Ma X., Yang J., Wu H., Jiang W., Ma Y., Ma Y. 2016. Growth analysis of cotton in competition with velvetleaf (Abutilon theophrasti). Weed Technology, 30: 123-136.

https://doi.org/10.1614/WT-D-15-00050.1

13. Martin R. J., Cullis B. R., McNamara D. W. 1987. Prediction of wheat yield loss due to competition by wild oats (Avena fatua). Australian Journal of Agricultural Research, 38 (3): 487-499.

https://doi.org/10.1071/AR9870487

14. Moon B. C., Cho S. H., Kwon O. D., Lee S. G., Lee B. W., Kim D. S. 2010. Modelling rice competition with Echinochloa crus-galli and Eleocharis kuroguwai in transplanted rice cultivation. Journal or Crop Science and Biotechnology, 13: 121-126.

https://doi.org/10.1007/s12892-010-0066-Z

15. Necajeva J., Dudele I., Mintale Z., Zarina L., Zute S., Bleidere M., Jansone Z. 2015. Increased infestation of agricultural land with wild oat (Avena fatua L.) in Latvia as related to variation of seed morphology and germination. $25^{\text {th }}$ NJF congress Nordic View to Sustainable Rural Development. Riga, Latvia, p. 75.

16. Odero D. C., Mesbah A. O., Miller S. D., Kniss A. R. 2010. Wild buckwheat (Polygonum convolvulus) interference with sugarbeet. Weed Technology, 24: 59-63.

https://doi.org/10.1614/WT-09-060.1

17. Pourreza J., Bahrani A., Karami S. 2010. Effect of nitrogen fertilization application on simulating wheat (Triticum aestivum) yield loss caused by wild oat (Avena fatua) interference. American-Eurasian Journal of Agriculture, 9: 55-61.

18. Rahman M., Khan A., Sadiq M., Rehman H. 2015. Competitive effects of wild oats on wheat yield and yield components under agro-ecological conditions of Dera Ismail Khan, Pakistan. Pakistan Journal of Weed Science Research, 21: 335-341.

19. Renton M., Chauhan B. S. 2016. Modelling crop-weed competition: why, what, how and what lies ahead? Crop Protection, 95: 101-108. https://doi.org/10.1016/j.cropro.2016.09.003

20. Ritz C., Kniss A. R., Streibig J. 2012. Research methods in weed science: statistics. Weed Science, 63: 166-187 https://doi.org/10.1614/WS-D-13-00159.1

21. Ritz C., Baty F., Streibig J. C., Gerhard D. 2015. Dose- response analysis using $R$. PLOS ONE, 10 (12): e0146021. https://doi.org/10.1371/journal.pone.0146021

22. Sexsmith J. J., Russell G. C. 1962. Effect of nitrogen and phosphorus fertilization on wild oats in spring wheat. Weeds, 11: 99-101. https://doi.org/10.2307/4040699

23. Sharma M. P., Vanden Born W. H. 1977. The biology of Canadian weeds. 27. Avena fatua L. Canadian Journal of Plant Science, 58: 141-157. https://doi.org/10.4141/cjps78-022

24. Sharma M. P., McBeath D. K., Vanden Born W. H. 1977. Studies on the biology of wild oats. II. Growth. Canadian Journal of Plant Science, 57 (3): 811-817.

https://doi.org/10.4141/cjps77-118

25. Trezzi M. M., Vidal R. A., Patel F., Miotto Jr E., Debastiani F., Balbinot Jr A. A., Mosquen R. 2014. Impact of Conyza bonariensis density and establishment period on soyabean grain yield, yield components and economic threshold. Weed Research, 55: 34-41. https://doi.org/10.1111/wre.12125

26. Uusna S. 2006. About biology and spreading of wild oat (Avena fatua L.) and possibilities of its control in Estonia. Transactions of ERIA, 71: 301-308 (in Estonian).

27. Willenborg C. J., May W. E., Gulden R. H., Lafond G. P., Shirtliffe S. J. 2005. Influence of wild oat (Avena fatua) relative time of emergence and density on cultivated oat yield, wild oat seed production, and wild oat contamination. Weed Science, 53: 342-352.

https://doi.org/10.1614/WS-04-124R1

28. Wilson B. J., Cousens R., Wright K. J. 1990. The response of spring barley and winter wheat to Avena fatua population density. Annals of Applied Biology, 116 (3): 601-609. https://doi.org/10.1111/j.1744-7348.1990.tb06643.x 
ISSN 1392-3196 / e-ISSN 2335-8947

Zemdirbyste-Agriculture, vol. 104, No. 3 (2017), p. 209-218

DOI 10.13080/z-a.2017.104.027

\title{
Tuščiosios avižos augalų gausumo poveikis vasarinių kviečių derliui
}

\author{
J. Necajeva, Z. Erdmane, A. Isoda-Krasovska, J. Curiske, I. Dudele, L. Gaile, L. Stirna, \\ K. Rancans, D. Polis, L. Spurina \\ Latvijos universiteto Latvijos augalų apsaugos tyrimų centras
}

\section{Santrauka}

Tuščioji aviža ((Avena fatua L.) yra svarbiausia piktžolè, plintanti javų pasèliuose Latvijoje. Siekiant prognozuoti galimus derliaus nuostolius esant ịvairiems tuščiosios avižos augalų tankiams, lauko eksperimentas buvo vykdytas ketverius metus, kiekvienais metais skirtingame vasarinių kviečių lauke pietinèje Latvijos dalyje. Buvo vertinama vasarinių kviečių ir tuščiųjų avižų augimo dinamika ir biomasè, lyginami grūdų derliai. Apdorojant kiekvienų metų duomenis buvo panaudoti Cousens (1985) derliaus nuostolių ir eksponentinis mažèjimo modeliai. Grūdu bei biomasès ir vasarinių kviečių bei tuščiụjų avižų derliai smarkiai skyrėsi tarp metų. Vidutinis vasarinių kviečių grūdų derlius visuose variantuose buvo 4443,38-7127,02 $\mathrm{kg} \mathrm{ha}^{-1}$. Pasirinkti tuščiųjų avižų tankiai buvo $0,1,2,4$, $8,16,32,100,200$ ir 500 augalų $\mathrm{m}^{-2}$. Lauke buvo pasiektas nuo 0 iki 332-466 augalų $\mathrm{m}^{-2}$ tankis. Priklausomai nuo metų, tuščiosios avižos daigai sudygo nuo 35 iki 56 dienų po sẻjos. Pirminę hipotezę, kad mažas tuščiosios avižos augalų tankis gali lemti vasarinių kviečių grūdų derliaus nuostolị, patvirtino lauko eksperimento rezultatai. Buvo gauta gana didele modelio parametrų variacija tarp bandymo metų, ịvairiais metais $5 \%$ derliaus nuostolis buvo nustatytas tuščiosios avižos augalų tankiui esant nuo 3 iki 54 augalų $\mathrm{m}^{-2}$. Vasarinių kviečių derliaus nuostolių ir tuščiosios avižos konkurencingumo variaciją galima aiškinti skirtingomis meteorologinèmis sąlygomis 2013-2016 m. ir nevienodu augalų maisto medžiagų kiekiu eksperimento laukuose. Siekiant nustatyti svarbiausius veiksnius, lemiančius tuščiosios avižos sukeltus derliaus nuostolius, reikia tolesnių tyrimų. Tyrimo rezultatai yra svarbūs siekiant nustatyti tuščiosios avižos javų pasėliams daromą žalą visame Baltijos regione.

Reikšminiai žodžiai: Avena fatua, derliaus nuostoliai, vasariniai kviečiai. 